\begin{tabular}{|l|l|l||}
\hline \multicolumn{2}{|c|}{ PublisherInfo } \\
\hline \hline PublisherName & $:$ & BioMed Central \\
\hline \hline PublisherLocation & $:$ & London \\
\hline \hline PublisherImprintName & $:$ & BioMed Central \\
\hline \hline
\end{tabular}

\title{
A new mechanism for hypertension
}

\begin{tabular}{|l|l|l||}
\hline \multicolumn{2}{|c|}{ ArticleInfo } \\
\hline \hline ArticleID & $:$ & 4174 \\
\hline \hline ArticleDOI & $:$ & $10.1186 /$ gb-spotlight-20010813-02 \\
\hline \hline ArticleCitationID & $:$ & spotlight-20010813-02 \\
\hline \hline ArticleSequenceNumber & $:$ & 245 \\
\hline \hline ArticleCategory & $:$ & Research news \\
\hline \hline ArticleFirstPage & $:$ & 1 \\
\hline \hline ArticleLastPage & $:$ & 3 \\
\hline \hline & & RegistrationDate : 2001-08-13 \\
ArticleHistory & $:$ & OnlineDate \\
\hline \hline ArticleCopyright & $:$ & BioMed Central Ltd2001 \\
\hline \hline ArticleGrants & $:$ & \\
\hline \hline ArticleContext & $:$ & 130592211 \\
\hline \hline
\end{tabular}


Hypertension is an important risk factor for death from stroke, heart disease, and kidney failure and affects about one-quarter of all adults word wide. In the August 10 issue of Science, Richard Lifton and colleagues at the Howard Hughes Medical Institute, Yale University School of Medicine in America, have identified two genes that cause pseudohypoaldosteronism type II (PHAII). This disorder causes hypertension via increased reabsorption of salt by the kidneys, and impaired secretion of potassium and hydrogen ions. (Science 2001, 293:1107-1112).

Wilson et al. began to unravel the genetics of this new pathway by identifying two types of families affected with hypertension. Each carried a specific genetic mutation, one on chromosome 12, and the other on chromosome 17. The breakthrough came when it was noticed that a genetic marker present in the normal chromosome 12 was absent in the mutated disease gene. Genomic analysis showed that the deletion was within a gene called $W N K 1$, expressed at high levels in the kidney, heart and skeletal muscle. WNKl codes for serine-threonine kinase, an enzyme that acts as a metabolic switch in cells.

The second group was found to have different, but overlapping deletions in WNK1, confirming the previous findings. Lifton acknowledged that the researcher who noticed the mutation had "an incredibly fortunate stroke of luck, without which we would still be searching". The WNKl gene was subsequently found to have five times as high expression in affected family members.

A second gene - WNK4 - was identified by searching the human genome database for WNKI-related genes on chromosome 17 and is located in the center of the region containing the PHAII gene. After screening several families, a section liable to small missense mutations was identified. The group hypothesizes that the mutations may increase the activity of the gene or its enzyme.

Both genes were localized to the kidney where the enzymes they produced were found in areas regulating the reabsorption or secretion of salt, potassium and hydrogen ions. One of them appeared in tight junctions, the junctions between cells that regulate the transport of certain molecules, such as chloride. Lifton and his colleagues suggest these studies show that the enzymes could be important in the regulatory pathway by which the kidney determines reabsorption of sodium, chloride, potassium, and hydrogen ions. Enzyme overactivity could increase reabsorption, expand blood volume and raise blood pressure.

The WNK4 gene also maps to the same region as the gene linked to blood pressure regulation in the long term Framingham Heart study, which has followed the health of a large group of people over many decades. Lifton said: "Since this is a new pathway proven to affect blood pressure, antagonists of this pathway might prove to be useful new medications".

These findings could result in a new class of drugs for treating increased blood pressure 


\section{References}

1. Wilson FH, Disse-Nicodème S, Choate KA, Ishikawa K, Nelson-Williams C, Desitter I, Gunel M, Milford DV, Lipkin GW, Achard JM, et al.: Human hypertension caused by mutations in WNK kinases. Science 2001, 293:1107-1112., [http://www.sciencemag.org/]

2. The Howard Hughes Medical Institute, [http://www.hhmi.org/]

3. Yale University School of Medicine, [http://info.med.yale.edu/ysm]

4. Framingham Heart study, [http://www.nhlbi.nih.gov/about/framingham/] 